\title{
PASSENGER PESTS OF FURNITURE AND WOOD PRODUCTS FROM ASIA
}

\author{
H.G. PEARSON ${ }^{1}$, M.F.S.W. FERNANDO ${ }^{1}$, K.L. PAICE ${ }^{1}$, Y. ANTONY ${ }^{3}$, \\ M.S. BULLIANS ${ }^{1}$, G.M. BURNIP ${ }^{2}$, K.J. FROUD ${ }^{1}$, S.J. BENNETT ${ }^{1}$, \\ C.A. MUIR ${ }^{2}$, D. GUNAWARDANA ${ }^{1}$, L.B. KUMARASINGHE ${ }^{1}$ \\ and B.J.T. MCCARTHY ${ }^{2}$
}
${ }^{I}$ Ministry of Agriculture and Forestry, PO Box 2095, Auckland, New Zealand ${ }^{2}$ Ministry of Agriculture and Forestry, PO Box 24, Lincoln, New Zealand ${ }^{3}$ MAF Quarantine Service, PO Box 39, Auckland, New Zealand

Corresponding author:Heather.Pearson@maf.govt.nz.

\begin{abstract}
An increase in the number of post-border interceptions of exotic pests that pose a threat to New Zealand's forest and amenity trees appears to reflect the increasing volume of imported Asian furniture and wood-related products into New Zealand. Live larvae and adult beetles have been found in a diverse range of wooden products from China a number of years after importation in raw, dressed, kiln-dried and coated timber. Often the first sign of insect activity is associated with noises emitted from the timber, discovery of frass or emergence holes. Notes are provided of post-border interceptions during the past 12 months including live sawyer beetle larva (Monochamus sp.) in imported saunas; two-striped long-horn beetle (Semanotus bifasciatus) in shelf kits; Auger beetle (Heterobostrychus sp.) in willow baskets; long-horn beetle (Xylotrechus grayi) in art easels; and Semanotus sp. in office furniture. Tracing determined that fumigation of the product at the point of origin was at times ineffectual.
\end{abstract}

\section{USING STEM-INJECTED INSECTICIDES TO PROTECT URBAN AMENITY TREES FROM HERBIVOROUS INSECTS}

\author{
S.F. GOUS and D.J. KRITICOS
}

\author{
Ensis, PB 3020, Rotorua, New Zealand
}

\section{Corresponding author: Stefan.Gous@ensisjv.com}

Five insecticides were evaluated for their efficacy to control herbivorous insects on Eucalyptus species. Insecticides were injected into the xylem of Eucalyptus cinerea, E. saligna and E. globulus. Uraba lugens (gumleaf skeletoniser) and Paropsis charybdis (Eucalyptus tortoise beetle) were used to bioassay a series of eight injection trials to assess insecticide levels through time in foliage from injected trees. Methamidophos proved to be highly effective in all bioassays on $U$. lugens and in one assay on $P$. charybdis. Methamidophos treatments consistently inflicted $100 \%$ mortality on insect larvae. Effective insect control was achieved within 7 days after injection and lasted beyond 80 days. No other selected insecticide achieved sustained or acceptable insect larval control. Stem-injection of insecticides appears to offer an effective and socially acceptable technique for protecting amenity-trees in situations where access is difficult or where other insecticide application techniques would be obtrusive. 